\title{
Disciplinary Procedure in Polish Special Services in the Light of the Concept of a Fair Trial Exemplified by the Disciplinary Procedure of the Internal Security Agency
}

\begin{abstract}
The incentive for contributing this paper is the planned great reform of Polish Special Services. The study attempts to formulate some requirements that should be met by disciplinary procedure. This goal is achieved by analyzing the effective disciplinary procedure in the Internal Security Agency (ABW), the largest branch of Polish Special Services, in the prism of the concept of a fair trial. The assessment of the disciplinary procedure in ABW leads to the conclusion that the effective law has many shortcomings. Major drawbacks are a lack of establishment of the supreme rule of disciplinary procedure and lack of a clear definition in the application of the general rules of criminal law within the domain of disciplinary procedure. The paper concludes that the shortfalls illustrated herein should be eliminated as fast as possible in order to adjust the disciplinary regime to modern standards.
\end{abstract}

Keywords: disciplinary procedure, special services, fair trial

Special services are specific institutions in a democratic state. The nature and burden of tasks special services are entrusted with empowers them with several rights whose exercise implies significant interference in the civil rights and freedoms. At the same time, statutorily determined tasks of special services entail that officers on duty encounter the most dangerous manifestations of crime, very often supported by organized crime groups, and sometimes (as in the case of spying) even foreign and hostile countries. The above facts imply that fulfilling operational, reconnaissance and procedural activities, officers of special services are subject to extremely intense and diverse pressure. In extreme cases such pressure may lead to the breach of their official oath and eventually result in the violation of law, improper performance of their duties or conduct contrary to the professional ethics.

The above mentioned circumstances imply that maintenance of discipline and respect of the law by special services officers are of incredibly considerable importance. One of the basic mechanisms assuring the observance of the rule of law 
within the sphere of special services are provisions creating the system of disciplinary liability ${ }^{1}$. Disciplinary norms must be formulated in a way which will make the ensuing model of liability an efficient and effective mechanism strengthening the rule of law in the operation of special services. At the same time, the envisaged solutions must respect general principles in force in a democratic state of law.

The media have recently informed about the plan of a profound reform of special services $^{2}$. For this reason, it appears necessary to analyze valid disciplinary provisions referring to the largest special service unit, i.e. Internal Security Agency (hereinafter $A B W)$. A purpose of the analysis is to draw attention to the existing imperfections of the current system of disciplinary procedure so that these flaws could be eliminated from the provisions on new services.

In the current legal status, disciplinary liability referring to ABW has been specified in Chapter 10 of the Act of 24 May 2002 on the Internal Security Agency and Intelligence Service 3 . Special procedural issues are contained in the Regulation of Prime Minister of 20 December 2004 on Granting Awards and Pursuing Disciplinary Proceedings against Officers of the Internal Security Agency ${ }^{4}$. In the face of this status,

1 Due to the functions and powers exercised by the special services, the issue of control over these institutions is an issue of particular importance in a democratic state of law. The model of controlof of special services that are currently in force in Poland is a multi-entity and multidimensional system. The control competencies over the operational and procedural activities of special services were entrusted to various entities that perform their activities in the field of different aspects of the activities of special services. Some control entities and their mechanisms are internal and located within a given service - undoubtedly this is a character of a system of disciplinary responsibility. More about the control of special services: A. Taracha, Czynności operacyjno-rozpoznawcze aspekty kryminalistyczne i prawnodowodowe, Lublin 2006, pp. 292317; J. Gryz, Teoretyczne aspekty funkcjonowania służb specjalnych RP, "Studia i materiały" 2012, No. 1, p. 86; D. Pożaroszczyk, Prawne mechanizmy służące zapewnieniu przestrzegania praworządności w wojskowych służbach specjalnych, (in:) M. Karpiuk, M. Czuryk (eds.), Prawo wojskowe, Warszawa 2015, pp. 271-284. Zagadnieniu kontroli nad służbami specjalnymi w perspektywie międzynarodowej poświęcona jest praca W.K. Smidt, U. Poppe, W. Krieger, H. Müller-Enbergs (eds.), Geheimhaltung und Transparenz: demokratische Kontrolle der Geheimdienste im internationalen Vergleich, Berlin - Münster 2007.

2 It seems that currently, two solutions are competing: the first assumes merging the Internal Security Agency with the AW and establishing the National Security Agency, the second transfer of all special services to the new Ministry of State Protection see: http://www.gazetaprawna.pl/ artykuly/995010,kaminski-zreformuje-sluzby-specjalne-ministerstwo-ochrony-panstwa.html (accessed: 26 November 2016).

3 Act of 24 May 2002 on the Internal Security Agency and Foreign Intelligence Agency (Journal of Laws of 2015 item 1929, as amended) [Ustawa z dnia 24 maja 2002 r. o Agencji Bezpieczeństwa Wewnętrznego oraz Agencji Wywiadu (tekst jedn. Dz.U. z 2015 r. poz. 1929 ze zm.).

4 Regulation of the President of the Council of Ministers of 20 December 2004 on the awarding of distinctions and conducting disciplinary proceedings against officers of the Internal Security Agency (consolidated text Journal of Laws of 2014, tem 60) [Rozporządzenie Prezesa Rady Ministrów z dnia 20 grudnia 2004 r. w sprawie udzielania wyróżnień i przeprowadzania 
the first requirement that should be considered in the provisions on the new special service is a postulate to abolish regulation of the issues concerning disciplinary liability in the sub-statutory $a c t^{5}$. The legitimacy of statutory regulation of disciplinary law is supported by the fact that even though the disciplinary system does not create a strictly criminal liability, it indeed completes and strengthens it in a specific way confirming the circumstance that punishment is not limited to the sphere of the state criminal law ${ }^{6}$. Disciplinary liability is by all means repressive liability ${ }^{7}$. Disciplinary provisions undeniably impose specific burdens on the persons involved, which may result in the restriction of civil rights and freedoms. Due to their severity, some disciplinary sanctions considerably surpass discomfort or pain of penalties and penal measures envisaged in the Criminal $\operatorname{Code}^{8}$. At the same time, in a democratic state of law, each normative regulation which permits interference in the civil rights and freedoms must have a status of an Act. It is explicitly and unanimously stipulated in Art. 31 par. 1 of the Constitution, according to which any limitation upon the exercise of constitutional freedoms and rights may be imposed only by statute.

Another problem ensuing from the valid disciplinary provisions referring to $\mathrm{ABW}$ is a lack of the supreme principle establishing the ABW officers' disciplinary liability. The fact that no structural principle of disciplinary law has been contained in the provisions on $\mathrm{ABW}$ while only prerequisites of this liability ${ }^{9}$ have been indicated, i.e. under Art. 144 and 145 of the Act on ABW, committing a crime or offence and

postępowań dyscyplinarnych wobec funkcjonariuszy Agencji Bezpieczeństwa Wewnętrznego (tekst jedn. Dz.U. z 2014 r. poz. 60)].

5 The same postulates S. Maj, Odpowiedzialność dyscyplinarna w służbach mundurowych. Możliwość uchwalenia wspólnej procedury, (in:) P. Jóźwiak, K. Opaliński (eds.), Węzłowe problemy prawa dyscyplinarnego w służbach mundurowych. II seminarium z cyklu „Odpowiedzialność dyscyplinarna w służbach mundurowych”, „Biblioteczka Kwartalnika Prawno-Kryminalistycznego" 2012, No. 2, p. 40 and 42. In this direction the draft (not enacted) of the new Internal Security Agency Act was also going in this direction, see: the draft of the Act on the Internal Security Agency of 1 August 2013, p. 86, avaibale on the website http://bip.msw. gov.pl/bip/projekty-aktow-prawnyc/2013/22385, Projekt-ustawy-o-Agencji-BezpieczenstwaWewnetrznego.html (accessed: 26 November 2016).

6 It is worth mentioning an opinion of M. Cieślak, who recognized the disciplinary law as a special branch or a generic version of criminal law, M. Cieślak, Polskie prawo karne. Zarys systemowego ujęcia, Warszawa 1994, pp. 22-23.

7 L. Gardocki, Prawnokarna problematyka sędziowskiej odpowiedzialności dyscyplinarnej, (in:) J. Giezek (re.), Przestępstwo - kara - polityka kryminalna. Problemy tworzenia i funkcjonowania prawa. Księga jubileuszowa z okazji 70. rocznicy urodzin Profesora Tomasza Kaczmarka, Kraków 2006, p. 191, see laso the judgmenet of the Regional Administrative Court in Poznan of 1 April 2009, IV SA/Po 475/08, Lex No. 533530.

$8 \quad$ P. Jóźwiak, Instytucja ułaskawienia - refleksje na płaszczyźnie odpowiedzialności dyscyplinarnej w służbach mundurowych, (in:) P. Jóźwiak, K. Opaliński (eds.), Węzłowe problemy..., op. cit., pp. 29-33.

9 On the distinction between the principle of responsibility and its premises, see. A. Brzozowski, M. Safjan, E. Skowrońska-Bocian, Zobowiązania, Warszawa 2004, pp. 206-207. 
breaking service discipline as well as other cases stipulated in the Act, ensues the question whether disciplinary liability referring to $\mathrm{ABW}$ is based on the principle of guilt, or whether it is objectivised liability based on the civil law structures of risk or equity ${ }^{10}$. It should be noticed here that disciplinary liability in uniformed services based directly on the principle of guilt has been enshrined by the Act on the Police ${ }^{11}$, State Fire Service and Prison Service ${ }^{12}$. On the account of the above solutions, a failure to determine in Art. 144 and 145 of the currently valid Act on ABW and AW (Intelligence Agency) the rule establishing disciplinary liability may imply that disciplinary liability of ABW officers does not depend on guilt thus bearing a status of objective liability entailing specific negative consequences solely on the basis of the existence of a causal connection between human conduct and the ensuing effect. The conceded justification of the claim according to which disciplinary liability could be based on the objective principle may be found in the intention to aggravate disciplinary provisions, which is motivated by the argument that a nature of threats being combated and assigned tasks whose fulfilment is of fundamental importance for Poland's security decide about the fact that liability within the ABW structures should be more severe than liability of police officers, firemen or prison service officers. Not negating the need for particularly harsh discipline in special services, it should be noticed that the purposively justified interpretation permitting objective attribution to the effect within the disciplinary system is absolutely inacceptable for axiological reasons. It has already been mentioned that disciplinary liability is a repressive liability which imposes on liable individuals specific burdens that by their very nature enter into the sphere of constitutionally protected rights and freedoms. The same as criminal sanctions, interference resulting from the application of the disciplinary system affects the most personal rights. This fact unequivocally supports subordination of disciplinary liability to the principle of guilt. In the judgment of 19 March 2007 rendered in connection with the restriction of the right to defence, the Constitutional Tribunal ${ }^{13}$ unambiguously decided that "Art. $42-45$ as well as Art. 78 of the Constitution shall be applied to assess not only strictly criminal regulations but, respectively, also other repressive regulations including disciplinary liability. Similar to criminal proceedings, the legislator is obliged to formulate provisions

10 It should be emphasized that in civil law, in relation to the liability of the ex-tort, the reference to the principles of risk and equity plays a complementary role. The guiding principle of the liability regime for tort is the principle of guilt, which is clearly expressed in art. 415 of the Civil Code. See more A. Brzozowski, M. Safjan, E. Skowrońska-Bocian, op. cit., pp. 206-208.

11 Act of 6 April 1990 on the Police (consolidated text Journal of Laws of 2016, item 1782) [Ustawa z dnia 6 kwietnia 1990 r. o Policji (tekst jedn. Dz.U. z 2016 r. poz. 1782)].

12 Act of 9 April 2010 - on the Prison Service (Journal of Laws of 2016, item 713) [Ustawa z dnia 9 kwietnia 2010 r. o Służbie Więziennej (Dz.U. z 2016 r. poz. 713)].

13 The judgment of the Constitutional Tribunal of 19 March 2007, K 47/05 (Journal of Laws of 2007, No. 57 , item 390). 
regulating any type of disciplinary proceedings in a manner assuring appropriate level of the right to defence in the substantive and formal aspect" ${ }^{14}$. Referring to the principle of proportionality, the Constitutional Tribunal also noticed in the above mentioned judgment that "with regard to uniformed services (as well as in other cases), limitation of the rights of individuals must be appropriately justified, in other words - it must be proportional". In the face of the invoked judgment, a repressive nature of ABW officers' liability decides about the application of guarantees and principles that are fundamental to the entire repressive law, including the principle of guilt, to this liability ${ }^{15}$. For this reason, evaluating disciplinary law referring to ABW, it should be claimed that a lack of explicitly regulated structural principle of this liability is by all means a defect of the currently valid Act. This evaluation is not changed by the content of Art. 28 par. 1 of the Regulation of Prime Minister of 20 December 2004 determining circumstances that should be taken into account when disciplinary penalty is imposed and restricted without reservation. This provision clearly points out to a degree of guilt as one of the circumstances that should be taken into account while imposing disciplinary penalty. This solution satisfies standards of contemporary repressive law assuming that severity of disciplinary penalty should not exceed a degree of guilt. Only punishment proportional to a degree of guilt, including the entire complexity of the situation in which the act ensuing disciplinary liability has been committed, and imposed on the basis of the analysis of all circumstances supporting both aggravation and mitigation of liability may be recognized as fair. However, pointing to guilt as a circumstance that should be taken into account in imposing penalty is not univocal with founding the disciplinary system on the principle of individual liability and culpability, and it is not sufficient as such. Considering that unambiguity of the principle of guilt as the basis of disciplinary liability in the light of literary, systemic and historical interpretation is not self-evident at all and, at the same time, including the fact that for guarantee reasons, disciplinary liability may only be based on this principle, the issue of the structural principle of disciplinary law should be univocally regulated.

A failure to unambiguously base the disciplinary system referring to ABW on the principle of guilt is naturally connected with a lack of reference to the fundamental principle of contemporary criminal law, i.e. the principle of assumed innocence ${ }^{16}$. The principle of assumed innocence is considered to be an immanent element of

14 An identical position regarding the validity under the disciplinary regime of all guarantees provided for in the second chapter of the Contitution was taken by the Constitutional Tribunal in the judgment of 8 December 1998, K 41/97 (Journal of Laws of 1998, No. 158, item 1043).

15 See also D. Korczyński, Wina jako przesłanka odpowiedzialności dyscyplinarnej funkcjonariuszy służb mundurowych, (in:) P. Jóźwiak, K. Opaliński (eds.), Węzłowe problemy..., op. cit., p. 14 and 30.

16 The principle of assumed innocence as a standard of the discplinary proceedings was indicated in the disciplinary proceedings applicable for the police, where art. $135 \mathrm{~g} \$ 2$ semtence 1 of the Act 
a democratic state of law connected with the principle of inalienable and inherent human dignity expressed in Art. 30 of the Polish Constitution. The guarantee to be treated as an innocent person has been expressed both in the Polish Constitution and binding acts of international law ${ }^{17}$. It is one of the fundamental principles designating individuals' position in the society and their relations to the authorities. Analyzing the operation of the principle of assumed innocence within the area of disciplinary law, we should pay attention to the judgment of the Constitutional Tribunal of 29 January $2002^{18}$, according to which "regulation of the principle of assumed innocence in the Constitution among provisions on freedoms and human and civil rights means the extended scope of application of the principle beyond the framework of criminal proceedings".

A failure to specify the principle upon which liability in disciplinary law referring to $\mathrm{ABW}$ is based on and, consequently, a failure to include the principle of assumed innocence therein, are derivatives of a general defect of current provisions manifested in a failure to regulate the issue of appropriate application of substantive criminal law regulations in disciplinary proceedings ${ }^{19}$. In the judgment of 5 November $2003^{20}$, analyzing provisions specifying the disciplinary system referring to common court judges, the Supreme Court decided that a lack of univocal regulation of the application of substantive criminal law regulations in disciplinary proceedings is an actual loophole of the legal system which must be filled in by interpretative endeavours. In the above invoked judgment, the Supreme Court decided that the application of the principle of accurate response ${ }^{21}$ codified in Art. $2 \$ 1$ point 1 of the Code of Criminal Procedure within the area of disciplinary law depends on the observance

of 6 April 1990 on the Police stipulates that the accused is considered innocent until his guilt is proved and confirmed by a valid decision.

The principle of assumed innocence was stipulated in $42 \$ 3$ of the Constitution, art. 14 of the International Covenant on Civil and Political Rights of 19 December 1966 (Journal of Laws of 1977, No. 38, item 167) and in art. 6 he Convention for the Protection of Human Rights and Fundamental Freedoms drafted in Rome of 4 November 1950 (Journal of Laws of 1993. No. 61, item 284).

18 Jugdement of the Constitutional Tribunal of 29 January 2002 r., K 19/01 (Journal of Laws of 2002, No 10, item 107).

19 On the need for according application of substantive law in the course of disciplinary proceedings see A. Herzog, Odpowiedzialność dyscyplinarna prokuratorów - co trzeba zmienić, „Prokuratura i Prawo" 2013, No. 12, p. 7; W. Kozielewicz, Stosowanie prawa karnego materialnego i procesowego w postępowaniu dyscyplinarnym w sprawach sędziów (zarys problematyki), (in:) L. Leszczyński, E. Skrętowicz, Z. Hołda (eds.), W kręgu teorii i praktyki prawa karnego. Księga poświęcona pamięci Profesora Andrzeja Wąska, Lublin 2005, p. 464.

20 The judgment of the Supreme Court of 5 November 2003, SNO 67/03, Lex 471880.

21 The principle of accurate response is valid also in the disciplinary law applicable to the Internal Security Agency. $\$ 53$ of the Prime Minister's Regulation of 20 December 2004 on the awarding of distinctions and conducting disciplinary proceedings against officers of the Internal Security Agency states that in matters not regulated in the regulation, with regard to the disciplinary 
of fundamental principles of criminal law in disciplinary proceedings. According to the Supreme Court, the fulfilment of the fundamental principle of accurate response, which within the area of disciplinary law takes a form of the principle ordering to hold disciplinary liable only a person who has committed an act ensuing disciplinary liability, requires the observance of basic principles of criminal law. It is also necessary to appropriately apply solutions determining the time when a prohibited act has been committed, the provisions on the form of an act and the form of its commission as well as principles specifying circumstances excluding liability. Being guided by the importance of appropriate application of criminal law provisions within the area of disciplinary law, the Supreme Court indicated a manner of using substantive law regulations in connection with a disciplinary case deciding that "during disciplinary proceedings, solutions envisaged in the Criminal Code should be referred to under the principle of analogia iuris. Obviously, the provisions of substantive criminal law must be appropriately applied in disciplinary proceedings, i.e. they must be: a) applied directly, b) applied with suitable modifications, or c) refused to be applied due to specific difference while particular prudence is necessary"22. The necessity to apply the provisions of substantive criminal law appropriately in disciplinary proceedings was confirmed by the Supreme Court in the judgment of 14 July $2009^{23}$. In this judgment the Supreme Court rightly noticed that the issue of applying the provisions of substantive criminal law in disciplinary proceedings is not self-evident. Considering the guarantee nature of criminal law and structures envisaged therein, a lack of obviousness with regard to the application of these regulations within the area of disciplinary system the Supreme Court has emphasized may entail farreaching, negative consequences. For this reason, new regulations thereon should be unambiguous.

A peculiar derivative of the insufficient inclusion of the criminal law structure in disciplinary law referring to $\mathrm{ABW}$ is the catalogue of disciplinary penalties contained in Art. 146 of the Act on ABW. Qualification of a warning (caution) of insufficient professional suitability to service as the most severe punishment, which is more

proceedings, the provisions of the Act of 6 June 1997. r. - Code of Criminal Procedure shall be applied accordingly.

22 Similar opinion about according application of the provisions of the Code of Criminal Procedure in the disciplinary proceedings was expressed by the Supreme Court in the Resolution of the Composition of the Seven Judges of 28 September 2006, I Kzp 8/06, Lex 193136, OSNKW 2006/10/87.z dnia 28 września 2006 r., I Kzp 8/06, Lex 193136, OSNKW 2006/10/87.

23 The judgment of the Supreme Court of 14 lipca 2009, SNO 42/ 09, Lex 575812, OSNKW 2010/5/44. Also the Regional Administartive Court in Warsaw in its judgment of 4 October 2006, II SA / Wa, 908/06, Lex 284495, declared that the appropriate application of substantive criminal law in the disciplinary proceedings was acceptable and held that "There is no reason to use other interpretations of unintentional guilt for the purposes of disciplinary proceedings against a Police officer than that which is set out in criminal law." Some doubts about this ruling was expressed by D. Korczyński, Wina jako przesłanka..., op. cit., pp. 15-16. 
lenient only from the dismissal from service, should be found inadequate. It seems that a much more painful penalty is stripping an officer off his rank. This penalty is more aggravated than a caution of insufficient professional suitability not only in the aspect of honour ${ }^{24}$ as it additionally entails more painful financial consequences. Pursuant to the Regulation of Prime Minister of 7 October 2002 on perks (allowances) to ABW officers' salaries ${ }^{25}$, the allowance for a Private amounts to PLN 600 whereas the allowance for the lowest rank in the Officer Corps, i.e. the allowance for a Second Lieutenant, amounts to PLN 980. With regard to higher ranks, the allowances are still higher. The allowance for a Colonel amounts to PLN 1160 whereas Brigadier General receives PLN 1270. At the same time, obtaining an officer rank under the ordinary course takes from eight to ten years.

Analyzing disciplinary law referring to ABW in the context of a fair trial, we should also draw attention to one of the fundamental elements of this concept, i.e. the right to effective measures of appeal and their exercise within the disciplinary system. Pursuant to $\$ 7$ point 2 of the Regulation of Prime Minister of 20 December 2004, ABW Chief Security Officer is competent to impose disciplinary penalty involving degradation to a lower rank, caution of insufficient professional suitability and the most severe disciplinary penalty - dismissal from service. At the same time, $\$ 32$ par. 4 stipulates that one is not entitled to appeal against the decision of ABW Chief Security Officer passed in disciplinary proceedings whereas the punished person may only apply for re-examination of his or her case. It should be noticed here that a repressive nature of disciplinary liability ensues that a strictly administrative application for re-examination of the case ${ }^{26}$ is not an adequate instrument of the rights protection within the area of disciplinary law. Discussing a profound reform

24 It should be noted that the deprivation of the rank of officer is also one of the consequences of imposing a criminal measure in the form of deprivation of public rights, which is a punitive measure pursuant to art. $40 \$ 2$ of the Penal Code and it may be ordered in the event of a sentence of imprisonment for a period not shorter than 3 years for an offense committed because of an incentive deserving special condemnation. The doctrine emphasizes that the penal measure in the form of deprivation of public rights derives from those penalties which resulted in deprivation of legal protection, expulsion, loss of worship and rights. In the Code of 1932, the equivalent of deprivation of public rights were additional penalties in the form of the loss of civil and civic rights of honorary rights. D. Szeleszczuk, Komentarz do art. 40, (in:) A. Grześkowiak, K. Wiak (eds.), Kodeks Karny. Komentarz. Warszawa 2012, p. 301.

25 Regulation of the President of the Council of Ministers of 7 October 2002 on allowances for the salary of officers of the Internal Security Agency (consolidated text Journal of Laws of 2016, item 1025) [Rozporządzenie Prezesa Rady Ministrów z dnia 7 października 2002 r. w sprawie dodatków do uposażenia funkcjonariuszy Agencji Bezpieczeństwa Wewnętrznego (tekst jedn. Dz.U. z 2016 r., poz. 1025)].

26 On the application for re-examination of the case see G. Łaszczyca, (in:) G. Łaszczyca, Cz. Martysz, A. Matan (eds.), Kodeks postępowania administracyjnego: Komentarz, Tom I do art. 1-103, Warszawa 2010, pp. 185-187. 
of special services, it is also worth considering postulates ${ }^{27}$ reported in the doctrine about transferring disciplinary jurisdiction from administrative courts to common courts, and more absolute (complete) subordination of disciplinary proceedings to the procedural criminal law ${ }^{28}$. The argument for leaving cases embracing disciplinary liability in the jurisdiction of administrative courts is a formal nature of disciplinary settlement which takes a form of an administrative decision ${ }^{29}$ as well as an administrative nature of service relationship ${ }^{30}$ arising in the course of appointment (promotion), which is characterized by a considerable degree of subordination and inequality. On the other hand, subordination of disciplinary cases to the jurisdiction of common courts is mainly supported by a repressive nature of disciplinary liability. Taking into account the above mentioned arguments, it should be held that the emphasized purpose of disciplinary proceedings, i.e. imposing a penalty for the committed offence, seems to be an argument deciding about determination of a proper procedure to resolve a disciplinary case. Even though disciplinary liability stems from a professional (service) administrative relationship, it finally becomes self-contained (self-reliant), and due to its focus on penalty, it becomes closer to a criminal law relationship. For this reason, a final decision on disciplinary liability should be made on the basis of the provisions of criminal procedure applied by a common court. Such a solution, including an autonomous nature of disciplinary liability, will permit to resolve disciplinary cases by the use of procedure which is better adjusted to this purpose and assures more guarantees.

Summing up the above presented comments on selected solutions of disciplinary law referring to $\mathrm{ABW}$, which have been inspired by the planned reconstruction of the system of Polish Special Services, it should be held that the regulation of

27 Statements of this content were also submitted during the nationwide conference "Models of the disciplinary proceedings in the light of the principles of a fair trial" organized by the Department of Criminal Proceedings of the Faculty of Law of the University of Białystok on 17 March 2014.

28 S. Maj, Odpowiedzialność dyscyplinarna..., op. cit., p. 41.

29 On the relationship between between the material nature of the case and the mode of its hearing see T. Romer, Właściwość sądów administracyjnych i sądów powszechnych w sprawach z zakresu prawa pracy, (in:) M. Błachucki, T. Górzyńska (eds.), Aktualne problemy rozgraniczania właściwości sądów administracyjnych i sądów powszechnych, Warszawa 2011, p. 59 and 64.

30 The view that the nature of a legal relationship is an argument for subjecting disputes arising from this relationship to the appropriate type of proceedings is expressed, inter alia, in: W. Sanetra, Właściwość sądów powszechnych (sądów pracy i ubezpieczeń społecznych) i sądów administracyjnych w sprawach z zakresu ubezpieczeń społecznych, (in:) M. Błachucki, T. Górzyńska (eds.), Aktualne problemy..., op. cit., p. 77. The real nature of the dispute in defining the proper procedure for its resolution requires to consider also M. Jaśkowska, Konstytucyjno prawne podstawy sądownictwa powszechnego i administracyjnego oraz delimitacja właściwości tych sądów, (in:) M. Błachucki, T. Górzyńska (eds.), Aktualne problemy..., op. cit., p. 26. At this point, it should be noted that following the postulate mentioned above, the Author expresses doubts about subjecting disciplinary matters to the jurisdiction of administrative courts, ibidem, p. 29. 
disciplinary system currently operating in $\mathrm{ABW}$ is far from being perfect ${ }^{31}$. Due to this, it should be postulated that creating new regulations on special services and establishing disciplinary provisions therein, the legislator should pay more attention to the requirements ensuing from the concept of a fair trial because only appropriate reference to this idea will allow to remove currently existing flaws of disciplinary law and adapt it to the standards a repressive regulation should satisfy in a democratic state of law.

\section{BIBLIOGRAPHY}

Brzozowski A., Safjan M., Skowrońska-Bocian E., Zobowiązania, Warszawa 2004.

Cieślak M., Polskie prawo karne. Zarys systemowego ujęcia, Warszawa 1994.

Gardocki L., Prawnokarna problematyka sędziowskiej odpowiedzialności dyscyplinarnej, (in:) J. Giezek (ed.), Przestępstwo - kara - polityka kryminalna. Problemy tworzenia i funkcjonowania prawa. Księga jubileuszowa z okazji 70. rocznicy urodzin Profesora Tomasza Kaczmarka, Kraków 2006.

Gryz J., Teoretyczne aspekty funkcjonowania służb specjalnych RP, “Studia i materiały” 2012, No. 1.

Herzog A., Odpowiedzialność dyscyplinarna prokuratorów - co trzeba zmienić. "Prokuratura i Prawo" 2013, No. 12.

Jaśkowska M., Konstytucyjnoprawne podstawy sądownictwa powszechnego i administracyjnego oraz delimitacja właściwości tych sądów, (in:) M. Błachucki, T. Górzyńska (eds.), Aktualne problemy rozgraniczania właściwości sądów administracyjnych i sądów powszechnych, Warszawa 2011.

Jóźwiak P., Instytucja ułaskawienia - refl eksje na płaszczyźnie odpowiedzialności dyscyplinarnej w służbach mundurowych, (in:) P. Jóźwiak, K. Opaliński (eds.), Węzłowe problemy prawa dyscyplinarnego w służbach mundurowych. II seminarium z cyklu „Odpowiedzialność dyscyplinarna w służbach mundurowych", "Biblioteczka Kwartalnika PrawnoKryminalistycznego" 2012, No. 2.

Korczyński D., Wina, jako przesłanka odpowiedzialności dyscyplinarnej funkcjonariuszy służb mundurowych, (in:) P. Jóźwiak, K. Opaliński (eds.), Węzłowe problemy prawa dyscyplinarnego w służbach mundurowych. II seminarium z cyklu „Odpowiedzialność dyscyplinarna w służbach mundurowych”, “Biblioteczka Kwartalnika Prawno-Kryminalistycznego” 2012, No. 2.

Kozielewicz W., Stosowanie prawa karnego materialnego i procesowego $\mathrm{w}$ postępowaniu dyscyplinarnym w sprawach sędziów (zarys problematyki), (in:) L. Leszczyński, E. Skrętowicz, Z. Hołda (eds.), W kręgu teorii i praktyki prawa karnego. Księga poświęcona pamięci Profesora Andrzeja Wąska, Lublin 2005.

Łaszczyca G., (in:) G. Łaszczyca, Cz. Martysz, A. Matan (eds.), Kodeks postępowania administracyjnego: Komentarz. Tom I do art. 1-103, Warszawa 2010.

31 In addition to the doubts discussed in the presented text, other issues concerning the disciplinary law of uniformed services are also raised in the literature on the subject. A series of questions regarding individual solutions of disciplinary regimes of uniformed services raises S. Maj, Odpowiedzialność dyscyplinarna..., op. cit., p. 41. 
Maj S., Odpowiedzialność dyscyplinarna w służbach mundurowych. Możliwość uchwalenia wspólnej procedury, (in:) P. Jóźwiak, K. Opaliński (eds.), Węzłowe problemy prawa dyscyplinarnego w służbach mundurowych. II seminarium z cyklu „Odpowiedzialność dyscyplinarna w służbach mundurowych”, "Biblioteczka Kwartalnika Prawno-Kryminalistycznego” 2012, No. 2.

Pożaroszczyk D., Prawne mechanizmy służące zapewnieniu przestrzegania praworządności w wojskowych służbach specjalnych, (in:) M. Karpiuk, M. Czuryk (eds.), Prawo wojskowe, Warszawa 2015.

Romer T., Właściwość sądów administracyjnych i sądów powszechnych w sprawach z zakresu prawa pracy, (in:) M. Błachucki, T. Górzyńska (eds.), Aktualne problemy rozgraniczania właściwości sądów administracyjnych i sądów powszechnych, Warszawa 2011.

Smidt W.K., Poppe U., Krieger W., Müller-Enbergs H. (Hg.), Geheimhaltung und Transparenz: demokratische Kontrolle der Geheimdienste im internationalen Vergleich, Berlin - Münster 2007.

Szeleszczuk D., Komentarz do art. 40, (in:) A. Grześkowiak, K. Wiak (eds.), Kodeks karny. Komentarz, Warszawa 2012.

Taracha A., Czynności operacyjno-rozpoznawcze aspekty kryminalistyczne i prawnodowodowe, Lublin 2006.

Sanetra W., Właściwość sądów powszechnych (sądów pracy i ubezpieczeń społecznych) i sądów administracyjnych w sprawach z zakresu ubezpieczeń społecznych, (in:) M. Błachucki, T. Górzyńska (eds.), Aktualne problemy rozgraniczania właściwości sądów administracyjnych i sądów powszechnych, Warszawa 2011. 